\title{
Koncepcje wychowania resocjalizującego na łamach „Gazety Penitencjarnej” (1967-1970)
}

\section{Wprowadzenie}

W okresie powojennym, przez długie lata wiedza o więzieniach polskich była dostępna jedynie dla funkcjonariuszy i przedstawicieli władzy państwowej. Wszelka aktywność dotycząca rzeczywistości więziennej podlegała ścisłej tajemnicy. W okresie kształtowania się nowego ustroju polityczno-społecznego na zasadnicze założenie polityki karania oraz organizację więzienia składało się uznanie więźnia za niebezpiecznego wroga (politycznego). Dominowała oficjalna ideologia marksistowska, w myśl której przestępczość jest silnie związana z kapitalizmem i nie ma miejsca w społeczeństwie, w którym wyeliminowany został tzw. konflikt klasowy. Zjawisko pospolitej przestępczości, zwłaszcza kradzieży, jest nieobecne w stosunkach społecznych, przepełnionych powszechną zgodą, sprawiedliwością i harmonią. Przestępczość w takich warunkach ustrojowych postrzegana była jako prymitywna forma oporu i dlatego nadawano jej charakter polityczny. Pospolity przestępca zyskiwał rangę rebelianta, wobec którego stosowano surowe represje karne, odpowiednie dla wrogów ustroju politycznego ${ }^{1}$.

W ideologii tej tkwią przyczyny bardzo restrykcyjnej polityki karnej i peni-

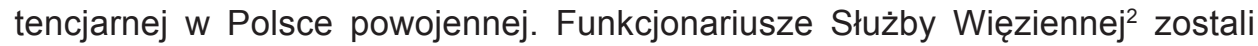

* Dr, Pracownia Pedagogiki Specjalnej, Wydział Nauk o Wychowaniu, Uniwersytet Łódzki, 91-433 Łódź, ul. Smugowa 10/12.

1 Szerzej pisze o tym m.in. P. Moczydłow ski, O sposobach wglądu w sekrety stosunków międzyludzkich. Przypadek instytucji totalnych, [w:] Poza granicami socjologii ankietowej, red. A. Sułek, K. Nowak, A. Wyka, Warszawa 1989, s. 31-59; t e n ż e, Więziennictwo - od systemu totalitarnego do demokratycznego, „Przegląd Więziennictwa Polskiego” 1994, nr 8, s. 9.

2 Do 1954 r. Straż Więzienna. 
zmilitaryzowani, a od więźniów wymagano bezwzględnej uległości i karności. Jak podkreśla Jerzy Górny, w pierwszej dekadzie PRL w zasadzie nie istniała w Polsce żadna koncepcja penitencjarna ${ }^{3}$. O hermetyczności systemu penitencjarnego tego okresu świadczy chociażby to, że w 1955 r. polscy penitencjaryści nie brali udziału w obradach I Kongresu ONZ w sprawie zapobiegania przestępczości i postępowania z więźniami.

Powyżej zarysowana sytuacja uległa zmianie dopiero $w$ drugiej połowie lat 50. XX w. W 1956 r. podjęto działania na rzecz budowy systemu penitencjarnego, nawiązując częściowo do rozwiązań międzywojennych. W podstawowej mierze kształtowanie się nowego systemu penitencjarnego w Polsce tego okresu opierało się na rozwiązaniach realizowanych $w$ innych państwach socjalistycznych, zwłaszcza Związku Radzieckim.

Proces wdrażania nowych rozwiązań organizacyjnych oraz opis „rzeczywistości" więziennej okresu PRL prezentowany był zazwyczaj na różnego rodzaju oficjalnych naradach, gdzie pokazywano sukcesy w zakresie resocjalizacji więźniów, ich coraz szersze zatrudnienie, podnoszenie poziomu wykształcenia funkcjonariuszy oraz zwiększanie „fachowości” służby więziennej. Był to wyidealizowany obraz pracy penitencjarnej. Istniał również inny, prawdziwy, prezentowany tylko wąskiemu gronu ważniejszych funkcjonariuszy ${ }^{4}$. Podstawy teoretycznoprawne oraz problematyka praktyki resocjalizacji więziennej podejmowana była na łamach pism o charakterze naukowym (np. „Przegląd Więziennictwa”) czy tzw. czasopism branżowych (np. „Gazeta Sądowa i Penitencjarna”).

Celem artykułu jest ukazanie celów, miejsca oraz rodzajów oddziaływań pedagogicznych wobec przestępców odbywających karę pozbawienia wolności, a także prezentacja i analiza wskazówek metodycznych do wychowania resocjalizującego w zakładach karnych Polski końca lat 60., zawartych w treściach artykułów adresowanych do kadry penitencjarnej. Analizie poddano treści artykułów przedstawionych na łamach "Gazety Penitencjarnej”, stanowiącej ważny (i odrębny) dział w "Gazecie Sądowej i Penitencjarnej”. Przedmiotem zainteresowania uczyniono doniesienia poświęcone wychowawczym aspektom resocjalizacji osób odbywających karę pozbawienia wolności, ze szczególnym uwzględnieniem opracowań o charakterze metodycznym.

Analizowane treści artykułów zawarte są w numerach „Gazety Penitencjarnej”, stanowiącej osobno wydzieloną część „Gazety Sądowej i Penitencjarnej”

${ }^{3}$ J. G ó rn y, Elementy indywidualizacji i humanizacji karania w rozwoju penitencjarystyki, Warszawa 1996.

${ }^{4}$ Problematyka ta jest szczegółowo opisana m.in. w artykule R. S z c z e p a n i k, Społeczno-polityczne determinanty postępowania z osobami pozbawionymi wolności w Polsce okresu minionego półwiecza. Implikacje dla praktyki resocjalizacji penitencjarnej, „Przegląd Badań Edukacyjnych” 2009, nr 9. Właściwie dopiero w latach 90. powstają dość liczne publikacje naukowe, które poświęcone są problematyce penitencjarnej, w tym roli społeczno-zawodowej więziennika oraz trudności towarzyszących odgrywaniu tej roli zawodowej (zob. także: K. B edyńs ki, Kształcenie zawodowe funkcjonariuszy więziennictwa w latach 1944-1989, [w:] Nabór i szkolenia funkcjonariuszy Służby Więziennej w polskim systemie penitencjarnym, Kalisz 1995, s. 14-32.

${ }^{5}$ W dalszej części opracowania tytuły te będą zapisywane odpowiednio: GSiP oraz GP. 
z lat 1967-1970. Wybór końca lat 60 . podyktowany był tym, że w tym okresie wyłania się nowa dziedzina wiedzy i praktyki, określana mianem pedagogiki penitencjarnej. Daje temu wyraz szereg artykułów poświęconych kwestiom „pedagogiki więziennej" na łamach omawianego czasopisma oraz eksponowana problematyka wychowania „poprawczego" i „reedukacyjnego” z zastosowaniem rozmaitych metod. Pod koniec lat 60 . ukazała się seria artykułów poruszających zagadnienie wykorzystywania w pracy penitencjarnej organizacji społecznych oraz dorobku środowiska naukowego. Prezentowane są doniesienia z seminariów naukowych, konferencji oraz kongresów, a także spotkań roboczych przedstawicieli środowiska penitencjarnego z naukowcami i studentami należącymi do kół naukowych. Spotkania te mają na celu „analizowanie i omawianie co trudniejszych problemów wychowawczych i wyjaśnianie ich w oparciu o badania naukowe" ${ }^{\prime \prime}$. Zaznacza się, że bramy „współczesnego" więzienia przekroczyła nauka i „sprawy reedukacji osłaniane dotychczas kurtyną milczenia znalazły się w kręgu zainteresowań naukowych i społecznych [...] zaczyna się doceniać pomoc, jaką społeczeństwo może okazać zakładom karnym w zakresie reedukacji więźniów i opieki postpenitencjarnej"7.

$\mathrm{Na}$ łamach czasopisma wyraźnie zaznaczają się treści poświęcone wychowawczym aspektom odbywania kary pozbawienia wolności, a także toczą się dyskusje oraz mają miejsce próby formowania tożsamości naukowej pedagogiki penitencjarnej.

\section{Problematyka prezentowana na łamach „Gazety Penitencjarnej”}

W dwutygodniku „Gazeta Sądowa i Penitencjarna” prezentowano artykuły poświęcone teorii i praktyce stosowania funkcjonującego prawa, analizowano zmiany ustawodawcze oraz poddawano interpretacji projekty tych zmian. Ważną część doniesień prasowych stanowiły opisy praktycznych rozwiązań organizacyjnych - głównie pracy organów ścigania i wymiaru sprawiedliwości oraz więziennictwa. Swoje stałe miejsce miały działy poświęcone charakterystyce ciekawych przypadków w pracy prawników (np. dział "Moja najciekawsza sprawa”)

Na przełomie lat 60. i 70. niezwykle żywe było wspomnienie zbrodni wojennych. Wiele uwagi poświęcano sprawom dotyczącym ścigania byłych zbrodniarzy nazistowskich, którzy w czasie okupacji hitlerowskiej działali na terenie Polski.

${ }^{6}$ Dla potrzeb praktyki penitencjarnej, GP $1968, \mathrm{nr} 48$, s. I.

7 Z. Le nar to w i c z, Więzienia i społeczeństwo, GP 1968, nr 48, s. I.

${ }^{8}$ Warunkiem „współredagowania” tego działu przez czytelnika było doświadczenie i prezentacja ciekawego przypadku w kontekście problemu prawniczego. Przykładem może być opis sprawy dotyczącej przestępcy, który podjął próbę ukrycia się przed organami ścigania poprzez operację zmiany płci (GP 1967, nr 1). 
Dziennikarze czasopisma śledzili losy funkcjonariuszy pozostających na wolności, którzy dotąd nie ponieśli stosownych konsekwencji swoich czynów. Podobne doniesienia miały często charakter śledztwa dziennikarskiego, co znajdowało swój wyraz w wymownych tytułach tych artykułów (np. Gdzie pan jest doktorze Rindfleisch ? $^{9}$ czy Kolejny proces zbrodniarzy z Oświęcimia ${ }^{10}$ ).

Bardzo silnie zaznacza się polityczny charakter czasopisma. Ważną i znaczącą objętościowo część artykułów stanowią te, których celem jest upowszechnianie treści związanych z działaniami PZPR i stronnictw politycznych, aktywnością rządu oraz organów władz regionalnych. Zarówno podejmowana tematyka, jak i interpretacja doniesień „partyjnych” w kontekście praktyki działania poszczególnych instytucji prawa ma bardzo silny wydźwięk polityczny, którego celem jest wzmacnianie istniejącego porządku ustrojowego. Niektóre sprawozdania z obrad władz partii opatrzone są wnioskami bezpośrednio dotyczącymi działalności więzień. Przedstawiane treści nawiązujące do funkcjonowania określonych instytucji odnoszone są do rozwiązań istniejących w Związku Radzieckim, z których należy czerpać inspiracje i przykład. Nie należą do rzadkości przedruki radzieckich artykułów prawniczych, kryminologicznych i psychologicznych. W tym miejscu należy zaznaczyć, że dość regularnie pojawiają się artykuły, stanowiące sprawozdania z działalności poszczególnych instytucji (np. sądy dla nieletnich, zakłady poprawcze i więzienia) w krajach innych niż socjalistyczne. Uwagę zwraca jednakże to, że w artykułach tych eksponowane są wady tamtejszych rozwiązań oraz są im przeciwstawiane dobre, socjalistyczne przykłady organizacyjne.

Od kwietnia 1967 r. w „Gazecie Sądowej i Penitencjarnej” wyodrębniono osobne miejsce poświęcone problematyce penitencjarnej. Do tej pory treści te były, co prawda, opisywane na wydzielonych kartach w środku gazety (tzw. „wkładka” do gazety), jednak od numeru 8/1967 została ona opatrzona tytułem „Gazeta Penitencjarna".

Problematyka „Gazety Penitencjarnej” skupia się wokół zagadnień organizacyjnych więziennictwa, przedstawione są zagadnienia kryminologiczne oraz tematyka pedagogiczna. Ważne miejsce zajmuje rubryka: „Sylwetki”, w której systematycznie opisuje się osiągnięcia zawodowe poszczególnych pracowników oraz analizuje się ich życiorysy zawodowe, zwykle w kontekście silnych związków funkcjonariusza z organizacjami społecznymi. Często podkreślana jest ideowość i zaangażowanie partyjne, któremu przypisuje się związek z silną motywacją do „lepszej” pracy ${ }^{11}$. W „Gazecie Penitencjarnej” doniosłe miejsce znajdują zagadnienia dotyczące codziennych trudności w pracy penitencjarnej, charakterystyki więźniów, problemów towarzyszących kontaktom z osadzonymi, a także kwestii przygotowania zawodowego funkcjonariuszy. Problematyka „pedagogiczna” skupia się wokół zasadniczych zagadnień, takich jak: nauka w zakładzie karnym, praca więźniów, wychowawczy charakter regulaminów i kar dyscyplinarnych, in-

\footnotetext{
9 Gdzie pan jest doktorze Rindfleisch?, GSiP 1967, nr 5.

10 Kolejny proces zbrodniarzy z Oświęcimia, GSiP 1968, nr 44.

11 Na przykład: Szacunek i podziw, GP 1967, nr 8.
} 
dywidualizacja w resocjalizacji oraz szeroko rozumiana działalność kulturalno-wychowawcza.

Należy zaznaczyć, że czasopismo było przeznaczone wyłącznie dla pracowników więziennictwa („do użytku wewnętrznego”) z zastrzeżeniem, by nie udostępniać go osadzonym.

\section{Badania pedagogiczne prezentowane na łamach „Gazety Penitencjarnej” (1967-1970)}

Analiza zawartości pisma w latach 1967-1970 pozwala sądzić, że problematyka pedagogiczna podejmowana była przez niewielką grupę uczonych. Przeważają opracowania o charakterze sprawozdawczym, omawiające istniejące przepisy i regulacje prawno-penitencjarne, kryminologiczne, psychologiczne i (w najmniejszym stopniu) pedagogiczne. Uwagę zwraca to, że w tytułach wielu artykułów dominują określenia sugerujące treści poświęcone wychowaniu, choć w rzeczywistości dotyczą innych zagadnień. Posługiwanie się określeniem „wychowanie" było charakterystyczne w przypadku referowania organizacji pracy penitencjarnej. Uważna lektura treści poszczególnych artykułów pokazuje, że odnoszono się w zasadzie do prawno-regulaminowych problemów pracy wychowawców, zabezpieczeń zakładów karnych czy fluktuacji kadry12.

Znaczna część artykułów o charakterze popularnonaukowym ma charakter przeglądu dotychczasowych wyników badań, w tym zagranicznych. Autorzy to najczęściej prawnicy specjalizujący się w zagadnieniach penitencjarnych i kryminologicznych oraz stosunkowo wąska grupa psychologów i pedagogów, zwykle związanych zawodowo z zakładami karnymi.

Opisy funkcjonowania więzień, prezentowane na łamach czasopisma, w propagandowy sposób ukazują sukcesy odnoszone na polu penitencjarnym, a także akcentują walory systemu socjalistycznego w procesie profilaktyki i resocjalizacji. Materiały stanowiące prezentację wyników badań pedagogicznych niewątpliwie należy traktować z bardzo dużą dozą ostrożności, ponieważ niektóre z nich - choć o naukowym profilu - nie są wolne od politycznych zniekształceń i propagandy.

Analiza przedstawionych w gazecie komunikatów z badań naukowych prowadzonych w tamtym okresie dowodzi wielu uproszczeń i fasadowości. Dominują wyniki badań, na które składają się deklaracje badanych więźniów (badania ankietowe), a częstym tematem dociekań przedstawianych na łamach czasopisma są zajęcia kulturalno-wychowawcze, organizowane na terenie zakładu karnego. Pewną egzemplifikacją charakteru badań oraz wniosków z nich płynących prezentowanych w gazecie są dane przedstawione w artykule pt. Formy wykorzystywania wolnego czasu w opinii więźniów ${ }^{13}$. Z przedstawianych danych wynika,

12 M.in. Rozwijanie procesu wychowawczego, GP 1970, nr 95.

13 W. S k o t n i c k i, Formy wykorzystywania wolnego czasu w opinii więźniów, GP 1969, nr 69, s. II. 
że więźniowie niedostatecznie korzystają z „bogatej” oferty zajęć proponowanych przez personel zakładów karnych. Autorzy badań uważają, że ciekawe i pożyteczne sposoby spędzania czasu wolnego przez więźniów na terenie zakładu karnego mogą powodować przyjęcie przez nich pewnych nawyków i ich utrwalenie, a następnie podejmowanie ich po opuszczeniu zakładu karnego. Badacze bezkrytycznie przytaczają uzyskane dane procentowe i optymistycznie zakładają, że aż 74\% więźniów będzie kontynuowało "nabyte” w zakładzie karnym sposoby spędzania czasu wolnego. Wątpliwości co do wartości tych analiz nasuwa m.in. to, że w grupie wymienianych przez autorów badań „pożytecznych” i mogących owocować przyjęciem nawyków w przyszłości są takie sposoby spędzania czasu wolnego, jak "odczyty z zakresu problematyki antyalkoholowej” czy konkursy „Zgaduj-zgadula”. Należałoby więc myśleć, że po opuszczeniu zakładu karnego więźniowie będą poszukiwać podobnych form spędzania czasu wolnego. Bezkrytycznie również przyjmują od badanych więźniów informacje o tym, iż „czują się zdemoralizowani i odczuwają potrzebę reedukacji”. Autorzy formułują życzeniowe wnioski, np. „stosunkowo duża liczba badanych tam więźniów dostrzega przydatność w procesie wychowawczym niektórych form organizacji wolnego czasu. Charakterystyczne jest to, że więźniowie w pozytywnej ocenie pominęli w zasadzie formy o charakterze wyraźnie rozrywkowym, a wysunęli na pierwsze miejsce te spośród nich, które faktycznie mogą przyczynić się do podlegania pozytywnym zainteresowaniom i przemiany ich mentalności” 14 .

Czasem opisywane sposoby pozyskiwania „szczerych” informacji ze strony badanych więźniów były wręcz kuriozalne, $\mathrm{np}$. byli więźniowie otrzymali na adres domowy ankiety do wypełnienia. Niektórzy z nich „nie skorzystali z anonimowości. Podali nazwiska i adresy. A to co napisali - co tu dużo mówić - stanowi rzecz krzepiącą. Wszyscy bowiem [...] prowadzą normalne życie"15. Trudno nie wątpić w rzetelność uzyskanych danych i wyrażać wiarę w to, że byli więźniowie przyznają się badaczom (reprezentującym administrację więzienną) do nielegalnej czy nieakceptowanej powszechnie aktywności społecznej.

Wnioski płynące $z$ „wyników badań” prowadzonych w tamtym okresie często wypływały z intuicyjnej wiedzy „badaczy”, ich własnych doświadczeń życiowych (zawodowych) oraz osobistych poglądów. Wywody te często obejmowały charakterystykę założeń organizacyjno-regulaminowych bez ukazywania głębszych mechanizmów funkcjonowania określonych aspektów odbywania kary pozbawienia wolności, a także bez wskazywania przeszkód i niebezpieczeństw tkwiących w strukturze i relacjach społecznych w zakładzie karnym. W rezultacie prowadzito to do afirmowania istniejących rozwiązań organizacyjno-regulaminowych oraz do formułowania naiwnych i mających życzeniowy charakter wniosków, jak taki, że „przestępca, który zetknął się z dolegliwością kary, będzie strzegł się przed popełnieniem nowych przestępstw"16.

14 Tamże.

15 M. M a n d u le w i c z, W Kamiennej Górze - młodociani, GP 1969, nr 86, s. II.

${ }_{16}$ M. Ru d nik, Warunki reedukacji młodocianych skazanych na krótkie kary pozbawienia wolności, „Zeszyty Naukowe Uniwersytetu Jagiellońskiego” 1970, t. 240, s. 49. 


\section{Zadania i miejsce pedagogiki penitencjarnej w systemie nauk penitencjarnych - cele wychowania resocjalizującego}

Inspiracją dla artykułów pod wspólnym tytułem Pedagogika penitencjarna, które podejmowały próbę określenia przedmiotu, zakresu oraz metod wychowania więźniów było wydanie pod koniec lat 60. radzieckiego podręcznika zatytułowanego Pedagogika pracy poprawczej. Była to pierwsza książka w bloku państw socjalistycznych, mająca charakter podręcznika poświęconego problematyce pracy penitencjarnej. Podkreślano, że „[...] w odróżnieniu od innych gałęzi pedagogiki, przedmiotem pedagogiki penitencjarnej nie jest wychowanie, lecz poprawa, reedukacja osób posiadających określone braki w wychowaniu, sprzyjające przestępstwom”17. Wątpliwości nie budziło to, że „podstawą oddziaływania penitencjarnego jest reżim, praca oraz działalność polityczno-wychowawcza. [...] Zadaniem pedagogiki penitencjarnej jest wskazywanie i uzasadnianie wymogów pedagogicznych i warunków, w których reżim, praca oraz działalność polityczno-wychowawcza będą najskuteczniej wykorzystane w procesie reedukacji i poprawy skazanych"18.

Wyróżniano dwa cele reedukacji i poprawy więźniów. Po pierwsze, cel minimalny, jakim jest „dążenie do wyrobienia u więźnia szacunku dla prawa, obowiązujących zasad współżycia społecznego, do wdrożenia go do społecznie pożytecznej pracy, przywrócenie go do normalnego życia"19. Po drugie, maksymalnym celem procesu pedagogicznego prowadzonego w zakładzie karnym jest „nie tylko dążenie do tego, by więzień nie popełniał nowych przestępstw, ale dążenie do całkowitego przeobrażenia ideowego i moralnego więźnia, do przekształcenia byłego przestępcy w świadomego członka społeczeństwa"20. Jednocześnie podkreślano jedność i rozłączność pojęć „poprawa” i „reedukacja” w praktyce oddziaływań pedagogicznych w zakładzie karnym. Otóż w zależności od stopnia demoralizacji jedni więźniowie podlegać będą procesowi jedynie poprawy, zaś inni - reedukacji. W odróżnieniu od „poprawy”, pod pojęciem „reedukacji” rozumie się „proces bardziej złożony, trudniejszy [...] przebudowę całej osobowości, całej psychiki człowieka: jego uczuć, woli, cech charakteru, nawyków i skłonności, zainteresowań i ideałów"21.

W innym artykule poświęconym problematyce pedagogiki penitencjarnej akcentowano to, że posługuje się ona własnymi metodami badania „osobowości i kolektywu więźniów”22. Czytelnicy zostali zapoznani z zasadniczymi metodami oraz technikami i sposobami ich wykorzystania. Wymieniono: eksperyment, rozmowę i korespondencję z krewnymi skazanego oraz techniki badania osobowości więźnia. Dużo miejsca poświęcono badaniu kolektywu więźniów, składu więźniów,

\footnotetext{
17 Pedagogika penitencjarna, GP 1968, nr 60, s. III.

18 Tamże.

19 Pedagogika penitencjarna (2), GP 1968, nr 62, s. II.

20 Tamże.

21 Tamże, s. III.

22 Pedagogika penitencjarna (6), GP 1969, nr 69, s. III.
} 
stosunku kolektywu więźniów wobec pracy, badaniu dyscypliny oraz ocenie aktywu więźniów. Zwracano uwagę na takie sposoby zbierania danych, jak: osobiste rozmowy z więźniami, inicjowanie zbiorowych dyskusji, uczestnictwo w zebraniach więźniów, zapoznawanie się z dokumentacją rady kolektywów, działalnością biblioteki itp.

Do zasad poprawy i reedukacji skazanych, czyli wyjściowych założeń, w których wyrażone są podstawowe wymogi dotyczące treści, organizacji i metod pracy z więźniem, zaliczono: „komunistyczną celowość i partyjność, ścisły związek procesu poprawy i reedukacji z pracą i życiem, wychowanie w kolektywie i poprzez kolektyw, indywidualne podejście do więźniów, łączenie wysokich wymagań w stosunku do więźnia z humanitarnym do nich stosunkiem, troska o ich rozwój i reedukację, oparcie procesu poprawy i reedukacji skazanych na ujawnieniu i umocnieniu ich cech pozytywnych, jedność, zbieżność, kolejność, konsekwencja oddziaływania wychowawczego"23. Podkreślano funkcje, jakie spełnia więzienie w państwie socjalistycznym: „zakłady karne mają szczególne zadanie socjalistycznego wychowania skazanych, a nie sposób sobie wyobrazić realizacji tego zadania bez rozwijania wśród więźniów pracy ideowo-wychowawczej"24. Więzienie przedstawiane jest jako jeden z ważniejszych „frontów ideologicznych"25, a istotnym przejawem słabości pracy penitencjarnej jest sprzyjanie temu, że „w celach toczą się niekontrolowane dyskusje polityczne”26. Sprawy polityczne są uważane przez wychowawców za „tabu” dla więźniów.

Szczególną uwagę poświęcono wychowawcom i nauczycielom. Żądano od nich nie tylko znajomości zadań i celów pedagogicznych, lecz także bezwzględnego podporządkowania całej swojej działalności dążeniu do osiągnięcia celów partyjnych. „Komunistyczna celowość i partyjność procesu poprawy i reedukacji znajduje swój wyraz w wyborze i stosowaniu metod, środków i form oddziaływań wychowawczych”27. Dopuszcza się metody, które „nie są sprzeczne z wymogami praworządności socjalistycznej (czyli są naukowo uzasadnione i humanitarne). Stosowanie środków przymusu nie wpisuje się w tę zasadę, podobnie jak nieumiejętne stosowanie nagród, które wyrabia u więźniów postawy egoistyczne, indywidualizm i osłabia poczucie odpowiedzialności przed społeczeństwem za popełnione przestępstwo"28.

Pedagogika penitencjarna pełni służebną rolę w stosunku do prawa. W zależności tej upatrywane są walory pedagogiczne: „fakt podporządkowania procesu pedagogicznego w zakładach karnych normom prawa penitencjarnego powinien być wykorzystany w celach pedagogicznych. Ścisłe wykonywanie dyspozycji zawartych w normach prawa penitencjarnego posiada znaczenie wychowawcze, ponieważ uczy więźnia zasad postępowania, wyrabia szacunek dla ustaw. [...] Zadanie polega na tym, żeby umieć w stopniu maksymalnym skutecznie i twórczo

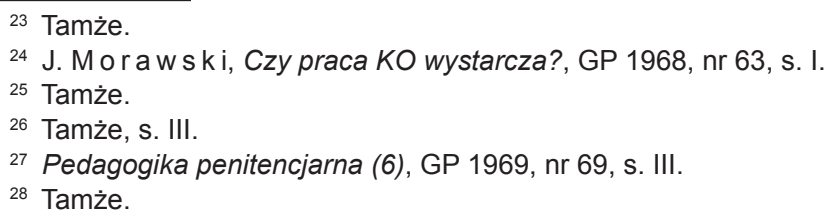


posługiwać się w celach pedagogicznych ograniczeniami, ustanowionymi przez ustawodawcę, a także metodami, środkami i formami wychowawczego postępowania nie pozostającymi w sprzeczności z ustawą"29.

W myśl zasad poprawy i reedukacji więźniów, wszelka skuteczna działalność wychowawcza nie jest możliwa poza kolektywem oraz poza pracą. Resocjalizacyjne walory pracy metodą kolektywu tkwią we włączeniu więźnia „w system wzajemnych zależności kolegi od kolegi. [...] Kolektywne stosunki nakładają na każdego więźnia określone obowiązki, za wykonanie których ponosi on moralną odpowiedzialność przed kolektywem i dyscyplinarną przed administracją [...]. Poprzez kolektyw wychowawca może szybciej i głębiej poznawać więźniów"30.

Pod pojęciem metod poprawy i reedukacji więźniów rozumie się „całokształt sposobów pedagogicznego oddziaływania na więźniów, których celem jest eliminowanie cech ujemnych i formowanie dodatnich, a także wdrażanie do słusznego postępowania" ${ }^{31}$. Doświadczenia radzieckie pokazują, że najczęściej stosowane metody w zakładach karnych powinny być następujące: przekonywanie, wdrażanie, wyróżnianie, przymus, przykład i zaufanie. Podkreśla się, że „w odróżnieniu od więzień w państwach kapitalistycznych, w których przymus jest podstawową metodą oddziaływania na więźniów, w zakładach karnych państw socjalistycznych przymus jest metodą pomocniczą. Stosuje się go wiec wobec tych więźniów, którzy nie bacząc na argumenty rozmowne, naruszają wymogi rygoru i dezorganizują działalność zakładu karnego. [...] Jako metodę oddziaływania pedagogicznego na więźniów, przymus stosuje się w ramach przymusu państwowego, jakim jest kara, związana z oddziaływaniem penitencjarnym"32. Podkreśla się również, że warunkiem skuteczności zastosowania przymusu wobec więźnia (pod postacią kategorycznego wymogu, uprzedzenia o pociągnięciu do odpowiedzialności karnej, kary, przymusu moralnego opinii publicznej) jest uprzednie upewnienie się, że „świadomość więźnia jest w znacznym stopniu przygotowana na jego przyjęcie"33. Wiele miejsca zajmuje opis udziału kolektywu więźniów w procesie stosowania przymusu jako oddziaływania pedagogicznego - większa część kolektywu powinna być przekonana o sprawiedliwości i konieczności przedstawionych żądań i winna stanąć po stronie wychowawcy ${ }^{34}$. Wspomniany powyżej "moralny przymus opinii publicznej” należy rozumieć jako „ocenę wykroczenia i postępowania więźnia przez kolektyw i pobudzenie go do zmiany swojego postępowania pod groźbą osądu moralnego i zmiany pozycji socjalno-psychologicznej więźnia w kolektywie (utrata autorytetu, bojkot itp.)"35.

Często prezentowane na łamach "Gazety Sądowej i Penitencjarnej” sprawozdania ze spotkań i narad partyjnych opatrywane są wnioskami i postulatami

\footnotetext{
${ }_{29}$ Pedagogika penitencjarna (3), GP 1968, nr 63, s. III.

30 Pedagogika penitencjarna (7), GP 1968, nr 73, s. III.

31 Pedagogika penitencjarna (2), GP 1969, nr 8, s. II.

32 Tamże.

33 Tamże.

${ }^{34}$ Pedagogika penitencjarna (9). Metody poprawy i reedukacji skazanych, GP 1969, nr 84, s. III.

35 Tamże.
} 
konieczności wdrożenia określonych idei w praktykę wychowawczą. Podkreśla się, że „na plan pierwszy wysuwa się zasada traktowania walorów ideowo-wychowawczych" ${ }^{36}$ w systemie oddziaływań na więźniów. Podobne postulaty odnosi się również do systemu kształcenia funkcjonariuszy penitencjarnych. Realizacja tej podstawowej zasady powoduje, że „konieczne jest doskonalenie programów nauczania z zapewnieniem właściwego miejsca dla problematyki ideowej i politycznej”37 oraz "większego nasycenia szkolenia treściami o charakterze społeczno-politycznym i humanistycznym"38. Akcentuje się to, że miarą zaangażowania nauczycieli i wychowawców w pracy wychowawczej jest ich szkolenie partyjne ${ }^{39}$. Niedostateczna świadomość „polityczna” roli zawodowej funkcjonariuszy sprzyja bowiem powstawaniu zjawisk patologii społecznych i niedociągnięć w miejscu pracy. Podnoszono również problem niskiego wykształcenia więzienników, wobec czego postulowano „potrzeby szkolenie w drodze różnych form całej kadry z naczelnikami Centralnych Więzień i pracownikami Centralnego Zarządu Więziennictwa włącznie; potrzeby prowadzenia agitacji na rzecz kończenia szkoły średniej przez funkcjonariuszy nie posiadających wykształcenia średniego; potrzeby zrobienia wszystkiego co możliwe w celu zwiększenia liczby funkcjonariuszy posiadających wykształcenie wyższe"40.

Charakterystyczne jest akcentowanie wychowawczej roli kary pozbawienia wolności, w tych tytułach artykułów, które w rzeczywistości stanowią uwagi krytyczne władz więziennictwa pod adresem pracowników, mające na celu ich zdyscyplinowanie, zmobilizowanie do intensywniejszej i bardziej sumiennej pracy. Analiza materiałów źródłowych dotyczących problematyki funkcjonowania zawodowego więzienników lat 60 . i 70 . pozwala sądzić, że w artykule tym w sposób zawoalowany wyrażono niezadowolenie oraz że ma on charakter dyscyplinujący kadrę penitencjarną ${ }^{41}$. Dość kategoryczny i surowy w swej konwencji

\footnotetext{
${ }^{36}$ Kierunki ofensywy polityczno-wychowawczej, GSiP 1967, nr 13, s. 1.

37 Tamże, s. 2.

${ }^{38}$ Na pierwszym planie - sprawy szkolenia, GW 1968, nr 63, s. II.
}

${ }^{39}$ Zgodnie z art. 5 dekretu o służbie więziennej z roku 1954, funkcjonariuszem mogła zostać osoba, która: posiadała obywatelstwo polskie; prezentowała odpowiedni poziom polityczno-moralny; legitymowała się odpowiednim wykształceniem ogólnym i przygotowaniem zawodowym; odbyła służbę wojskową lub była przeniesiona do rezerwy oraz cechowała się odpowiednim stanem zdrowia. W rzeczywistości podstawowym wskaźnikiem „zdatności” funkcjonariusza była jego postawa polityczna. Kwestia wykształcenia i predyspozycji osobowościowych nie była brana pod uwagę. Kariera zawodowa i awanse były uzależnione nie od poziomu wykształcenia, lecz od liczby przebytych szkoleń i kursów politycznych oraz postawy „ideologicznej”. Niskie kompetencje zawodowe oraz brak elementarnej wiedzy psychologicznej i pedagogicznej powodowały, że funkcjonariusze sięgali po alkohol i przemoc w celu minimalizowania stanów frustracyjnych i poczucia niemocy, bezradności w kontaktach z osadzonym (szerzej: R. S z c z e p a n i k, K. S o b o ń s ki, Status społeczno-zawodowy funkcjonariusza służby więziennej w Polsce, [w:] Opieka i wychowanie w instytucjach wsparcia społecznego. Diagnoza i kierunki przeobrażeń, red. R. Szczepanik, J. Wawrzyniak, Łódź 2012.

40 Na pierwszym planie - sprawy szkolenia, GP 1968, nr 63, s. II.

${ }^{41}$ Częste były przypadki alkoholizowania się funkcjonariuszy na terenie zakładu karnego w czasie pracy, stosowanie przemocy, wykorzystanie więźniów do pracy przy budowie np. prywatnych domów itp. (m.in. R. Szczepanik, Społeczno-polityczne determinanty postępowania z osobami pozbawionymi wolności w Polsce okresu minionego półwiecza. Implikacje dla praktyki resocjalizacji penitencjarnej, „Przegląd Badań Edukacyjnych” 2009, nr 9. 
tekst pt. Rozwijanie procesu wychowawczego adresowany jest do pracowników penitencjarnych. Zwraca się „szczególną uwagę na pewne niekorzystne zjawiska hamujące postęp, osłabiające efekty pracy wychowawczej oraz zadania, jakie w związku z potrzebą ich wyeliminowania stoją przed ogółem funkcjonariuszy pracowników ZK (zakładów karnych) i AŚ (aresztów śledczych)"42. Uwagę zwracają prezentowane zestawienia statystyczne, m.in. te, że sukcesem było zmniejszenie liczby wykroczeń dokonywanych przez funkcjonariuszy w 1969 r. o 35\%, ubolewa się nad zbyt dużą fluktuacją kadry i niedostatkami kadrowymi. W celu poprawy zachowań i wizerunku funkcjonariusza przygotowano dokument pt. Zasady postępowania i zachowania się funkcjonariuszy SW, pomocny w procesie kształtowania się właściwych postaw zawodowych kadry penitencjarnej.

W tym samym numerze znajdujemy obszerne opracowanie pt. Kim jest wychowawca ${ }^{43}$. Autor odwołuje się do koncepcji Antoniego Makarenki, omawia jego poglądy. Jednocześnie wskazuje przeszkody organizacyjne we wdrażaniu w życie zasad pedagogiki Makarenki. Przywołuje przykłady ilustrujące absurdalne wymagania stawiane przed wychowawcami. „W zakładzie karnym w Łodzi-Sikawie wychowawca demonstrował mi naręcze zeszytów skrzętnie ponumerowanych, do których zgodnie z planem pracy powinien wszystko wpisywać: od rozmów z rodzicami i skazanymi, ewidencji próśb, zażaleń i potrzeb, do uwag o stanie zdrowia więźniów i inwentarza w oddziale"44. Autor stawia ważne pytania o status wychowawcy (problematyka ta podejmowana jest także w serii artykułów o charakterze ironicznym i pod znamiennym tytułem Omnibusy ${ }^{45}$ ). Problem leży w zbiurokratyzowanym systemie pracy, którego częścią jest wychowawca, a ich zmniejszenie spowodowałoby usprawnienie pracy wychowawczej. Dodatkową barierę we właściwym wykonywaniu obowiązków stanowi zbyt duża liczba więźniów, przypadających na jednego wychowawcę (dla przykładu w 1968 r. na jednego wychowawcę przypadało średnio 200 osadzonych; przeciętna liczba w zakładach karnych w województwie bydgoskim wynosiła nawet 300$)^{46}$. Henryk Machel stawia ważne pytanie o to, „ile czasu może poświęcić wychowawca jednemu więźniowie" i dokonuje kalkulacji, która dowodzi bezsensowności podobnych rozwiązań oraz niemożności sumiennego wywiązywania się z zadań wychowawczych: „[...] Uwzględniając fakt, że wychowawca pracuje 8 godzin dziennie i powinien oddziaływać każdego dnia (proces wychowawczy musi być ciągły) na około 300 więźniów [...] wychowawca musiałby codziennie rozmawiać z 50 więźniami. Wówczas z każdym więźniem w ciągu jednego tygodnia mógłby rozmawiać 6 minut. W okresie miesiąca wychowawca mógłby zatem 4 razy rozmawiać z każdym więźniem łącznie przez 24 minuty"47.

\footnotetext{
42 Rozwijanie procesu wychowawczego, GP 1970, nr 95, s. II.

43 Z. L e na r to w ic z, Kim jest wychowawca, GP 1970, nr 95, s. I.

44 Tamże, s. II

45 Por. także: Z. P oll o c h, Trzeba pomóc „omnibusom”, GSiP 1967, nr 1.

46 H. Ma chel, Czas pracy wychowawcy, GP 1968, nr 50, s. II.

47 Tamże, s. III.
} 
Warto zaznaczyć, że zagadnienie trudności pracy więziennika poruszane jest także w artykułach, które stanowią sprawozdania oraz opisy działalności jednostek penitencjarnych w krajach spoza bloku socjalistycznego. Charakter wniosków oraz uogólnień w tego rodzaju artykułach wyraźnie sugeruje podobieństwo problemów, z jakimi boryka się więziennictwo - bez względu na ustrój polityczno-społeczny. Dominuje wątek trudności w doborze odpowiedniej kadry penitencjarnej oraz specyfiki pracy więziennika, która silnie wiąże się z brakiem poczucia bezpieczeństwa, obawą przed atakami czy ucieczkami więźniów, „które to niepokoje prowadzą do najprawdziwszych obsesji [...]. Rekrutacja do administracji więziennej nie sprzyja, nie stwarza szansy stworzenia inteligentnej, pojętnej kadry. Administracja więzienna muszą się często zadowalać pracownikami, których wyzbyła się policja lub żandarmeria" 48 .

\section{Problematyka metod, form i środków oddziaływania wychowawczego na więźniów}

We wspomnianym wcześniej artykule Henryka Machela poświęconym trudnościom w codziennej pracy wychowawczej z więźniami autor zestawia nadmierną liczbę więźniów przypadających na jednego wychowawcę z wielością obowiązków, jakimi obarczony jest „pedagog więzienny”. Obowiązki te wynikają ze stawianych przed nim zadań organizacyjno-wychowawczych. Autor artykułu wymienia je, pragnąc przeforsować tezę o przepracowaniu i nadmiernym obciążeniu pracą wychowawców, jednakże zaprezentowane przez niego rodzaje prac i codziennych zobowiązań pokazują formy oraz środki oddziaływania wychowawczego na więźniów. Bezpośrednia i indywidualna praca wychowawcy z więźniem, według Machela, jest co prawda teoretycznie możliwa, ale „[...] Możliwość ta pozostaje utopią, bowiem wychowawca w tym układzie rzeczy nic innego nie powinien robić [...] gdzie zatem czas na sporządzanie notatek, na wizytacje cel, na wizytacje miejsc pracy, prowadzenie zajęć k.o., hospitowanie zajęć k.o, na prowadzenie dobrych zapisów w karcie indywidualnej i kwestionariuszu więźnia? Jak wygospodarować czas na przygotowanie się do prowadzenia zajęć k.o, sporządzanie konspektu, na napisanie pogadanki do radiowęzła, na indywidualne poradnictwo czytelnicze, na analizę wytworów własnej działalności więźniów, na pisanie opinii o więźniach. Jak można znaleźć czas na cenzurowanie co poniedziałek około 200 listów i traktowanie ich jako materiałów osobopoznawczych?"49. Z powyższego wynika, że ważne miejsce w pracy wychowawczej z więźniami zajmowały zajęcia kulturalno-oświatowe. W licznych artykułach analizuje się ich celowość oraz funkcje.

48 W. Skuls k a, Zawód, który pragnie być doceniany, GP 1968, nr 44, s. II.

49 H. Machel, Czas pracy wychowawcy..., s. III. Ponadto autor zwraca uwagę na inne obowiązki należące do wychowawców, w tym rozliczenia i sprawozdania finansowe, troska o wyposażanie pomieszczeń w stosowny sprzęt i inne. 
Praca kulturalno-oświatowa traktowana jest przede wszystkim jako narzędzie oddziaływania ideowego, a także „(poza pracą produkcyjną i nauką) główna forma pracy wychowawczej-penitencjarnej, zmierzającej do przebudowy kryminalnych postaw skazanego. Ponadto ze swej istoty praca kulturalno-oświatowa ma dostarczyć więźniom wiedzy, rozwijać zainteresowania, podnosić ich poziom kulturalny i stanowić niezbędną dla rozładowania napięć psychicznych rozrywkę" ${ }^{50}$. Akcentuje się wychowawcze elementy pracy k.o., które zapewnia specjalny dobór filmów, programów telewizyjnych i radiowych, dozwolonych dla więźniów, książek i czasopism oraz włączanie osadzonych w szereg obchodów świąt państwowych.

Krytyce poddawana jest praktyka sięgania po pracę kulturalno-oświatową w celach innych niż wychowanie. Udział więźniów w organizowanych imprezach nie może być powszechny, a powinien stanowić nagrodę za dobre wyniki w pracy i wzorowe przestrzeganie dyscypliny ${ }^{51}$. Zajęcia kulturalno-oświatowe zorientowane są na efektywne wypełnienie czasu wolnego więźniów. W zakładzie karnym przełomu lat 60 . i 70 . formy zagospodarowania czasu wolnego więźnia miały do spełnienia takie funkcje, jak: reedukacja, odpoczynek, rozrywka i samokształce$n^{n}{ }^{52}$. Podkreśla się konieczność brania pod uwagę potrzeb więźniów podczas organizowania poszczególnych form spędzania czasu wolnego (np. treści pogadanek, odczytów wygłaszanych bezpośrednio lub za pośrednictwem radiowęzła). Należy zaznaczyć szczególną rolę więźniów - aktywistów k.o. w zakładach karnych. Analiza treści artykułów poświęconych tej problematyce pozwala sądzić, że były to osoby ściśle współpracujące z personelem penitencjarnym, inicjujące określone akcje wśród współwięźniów oraz sprawozdające wychowawcom określone nastroje i sytuacje, mające miejsce w relacjach nieformalnych ${ }^{53}$.

Wiele uwagi poświęcono opisowi trudności wychowawczych oraz problemów z zachowaniem się więźniów. Część artykułów stanowi opis praktycznych rozwiązań, których celem jest minimalizowanie negatywnych zjawisk utrudniających właściwy proces reedukacji. Sukcesy resocjalizacyjne, których miarą jest mała liczba ucieczek i oddaleń się więźniów oraz niski poziom wykroczeń mogą być osiągane np. za pomocą sumiennego przestrzegania regulaminów oraz znajomości planów pracy. Podnosi się konieczność systemowego podejścia do wychowania więźniów, które przeciwstawiane jest „improwizacji wychowawczej”" „Znajomość planów pracy, regulaminu, wspólne dyskutowanie zamierzeń i inicjatyw na naradzie partyjno-służbowej z udziałem członków komisji penitencjarnej" ${ }^{55}$ służy skoordynowaniu oddziaływań wychowawców. Prezentowano liczne sukcesy organizacyjne w zakładach karnych. Wiele miejsca poświęcono szukaniu nowych

\footnotetext{
50 J. Morawski, Czy praca..., s. I.

51 Tamże.

${ }^{52}$ W. S k o t n i c ki, Formy wykorzystywania wolnego czasu..., s. II.

${ }_{53}$ M.in.: J. Morawski, Czy praca..., s. I.

${ }^{54}$ W Mielęcinie, GP 1967, $\mathrm{nr} 20$, s. II.

55 Tamże.
} 
metod oddziaływań na więźniów oraz uwarunkowań ich skuteczności. Dla przykładu opis funkcjonowania zakładu w Mielęcinie, w którym nacisk kładziono na „jednolitość wychowawczego oddziaływania, wolną progresję oraz kontakty z organizacjami społecznymi"s6 i pozawięziennymi środowiskami pracy. Do obowiązków wychowawcy wpisano tu „odwiedzanie więźniów w szkole, na stanowiskach pracy, przysłuchiwanie się odpowiedziom na lekcjach więźnia, występowanie z głosem doradczym na zebraniach rady pedagogicznej w szkole"57. Ponadto wychowawca ma obowiązek kontaktowania się z przełożonymi więźnia w miejscu jego pracy.

Problematyka kar dyscyplinarnych w procesie wychowawczym stanowi kolejną grupę problemów poruszanych na łamach „Gazety Penitencjarnej”. Rodzaje kar dyscyplinarnych określają odpowiednie przepisy prawne i regulaminowe. Problematyka stosowania tych kar jest podejmowana w kontekście psychologii i praktyki penitencjarnej. Omawia się warunki skutecznego oddziaływania kary, bowiem „kara nie tylko powstrzymuje, ale powoduje wzmożenie negatywnych reakcji i postaw"58. Podkreśla się konieczność stosowania zindywidualizowanych środków oddziaływania na więźnia i unikanie utartych rozwiązań. Postuluje się potrzebę dbania o silny związek między karą a przyczyną jej stosowania (np. pozbawienie uczestnictwa w seansie filmowym winno być konsekwencją niekulturalnego zachowania się więźnia w czasie oglądania filmu - pozbawienie więźnia możliwości korespondencji nie jest $w$ tym przypadku karą adekwatną). Krytyce poddawana jest zasadność nadmiernego stosowania kary „twardego łoża”59. Ponadto przestrzegano przed zasadniczym błędem, jakim jest stosowanie kary wobec więźnia, która dla danej osoby ma walory nagrody (np. ukaranie samotnym zamknięciem w celi izolacyjnej więźnia, starającego się o pojedynczą celę). Kolejno analizowanym problemem są ograniczenia rodzajów stosowanych kar, zwłaszcza wobec najbardziej zdemoralizowanych recydywistów: „[...] istnieje pewna liczba więźniów, których po prostu nie można ukarać, nie można. Bo nie ma czym. [...] Bo czym ukarać więźnia, który nie prowadzi korespondencji, z widzeń nie korzysta, paczek nie otrzymuje, środków na zakup artykułów żywnościowych nie posiada, do twardego łoża się przyzwyczaił (lub ze względu na stan zdrowia nie można go tą karą karać) i w dodatku nie pali papierosów"60.

Uwagę zwraca seria artykułów poświęconych problematyce samorządów więziennych. Rozwój tych form „wychowania” więziennego przypada na koniec lat 50.61 Wartości wychowawcze samorządu więźniów tkwią „,W podstawach

56 Tamże.

57 Z. Le narto w ic z, W poszukiwaniu nowych metod, GP 1969, nr 78, s. II.

58 S. Seredziń s ki, Czy kara wychowuje?, GP 1967, nr 35, s. II.

59 Kara ta polegała na czasowym pobycie w specjalnie do tego przygotowanej celi. Rolę łóżek odgrywały przymocowywane na dzień do ściany drewniane prycze. Więzień pozbawiany był materaca i posłania.

${ }^{60}$ W. Poznaniak, B. Pawelczyk, Pedagogizacja karania dyscyplinarnego, GP 1969, $\mathrm{nr} 86, \mathrm{~s} . \mathrm{II}$.

61 W oparciu o założenia pedagogiki A. Makarenki (zwłaszcza w zakresie organizacji tzw. samorządu więźniów) funkcjonował zakład dla młodocianych w Jaworznie. Problematykę tę opisuje m.in. W. The is s, Zniewolone dzieciństwo, Warszawa 1996. 
makarenkowskiej pedagogiki wychowania w kolektywie"62, zaś idee i zasady zostały sprecyzowane we wskazówkach Wydziału Penitencjarnego CZW dotyczących „Organizacji kolektywnych form pracy wychowawczej z więźniami” (1963). W treść artykułów „Gazety Penitencjarnej” wpisuje się szereg sprawozdań z „praktycznego sprawdzenia słuszności idei wychowawczych”63 pedagogiki Makarenki. Idea ta postrzegana jest jako „żywa i twórcza” koncepcja pracy penitencjarnej. W odniesieniu do organizacji pracy penitencjarnej w więzieniu sprowadza się przede wszystkim do wykorzystania pracy więźniów w celu tworzenia kolektywów (grup produkcyjnych). Mankamentem była zbyt duża liczba więźniów (np. 150-osobowe zespoły kolektywne) oraz to, że w skład kolektywów wchodzili nie tylko więźniowie pracujący w jednym zakładzie, lecz także zatrudniani poza jednostką penitencjarną, w różnych miejscach, co utrudniało „kierowanie procesami, jakie zachodzą w kolektywie, uniemożliwiało nieraz prowadzenie obserwacji zachodzących w nim zjawisk, które ginęły w masie". Tworzone są rady kolektywów oddziałowych, których przedstawiciele to więźniowie grupowi mniejszych grup produkcyjnych. Podstawową komórkę wychowawczą stanowi grupa produkcyjna więźniów, zespół ludzi, którzy zamieszkują wspólną celę, wspólnie pracują i wykonują te same czynności. Zdaniem promotorów tego programu wychowawczego, problemy i niedociągnięcia można przezwyciężać dzięki wnikliwej analizie koncepcji kolektywnego wychowania A. S. Makarenki. Nazywał on kolektywem podstawowym zespół ludzi (liczący 7-15 członków), stanowiących brygadę produkcyjną, klasę szkolną, którzy ze względu na związek produkcyjny lub inne czynniki im wspólne byli z sobą powiązani, współdziałali na zasadzie przyjacielskiej. Jeśli chodzi o funkcje i cel wychowania w ramach kolektywu podstawowego, to grupa produkcyjna stanowi kolektyw podstawowy, w którym prowadzona jest „obróbka jednostki dla wyrobienia takich cech charakteru i postępowania, które potrzebne są społeczeństwu socjalistycznemu"64. Rola grupy produkcyjnej zostaje świadomie wyeksponowana jako kolektyw podstawowy, który tworzy podstawowe środowisko wychowawcze i w którym możliwe jest zespolenie członków oraz dokonuje się mobilizacja do jak najlepszej pracy, zachowania się w pracy i przestrzegania przepisów z nią związanych. Tak rozumiana metoda wpisuje się w zasadę o samowychowaniu. Dodatkowo w praktyce kolektywu produkcyjnego następuje wzajemne rozliczanie się z błędów: dane zachowanie jednego członka jest analizowane przez pozostałych, a następnie przyjmowany jest wspólny punkt widzenia sytuacji problemowej i sposób jej przezwyciężania. Aby metoda ta mogła być skutecznie realizowana, konieczna jest bezwzględna znajomość koncepcji wychowania w kolektywie Makarenki oraz umiejętność odnajdowania w niej inspiracji dla własnej pracy pedagogicznej. Wymagane jest odpowiednie traktowanie kolektywu produkcyjnego, tak, by „aktyw zespołów samorządowych był w pełni przekonany o tym, że ich kolektyw, ich rada stanowią środowisko wychowawcze, którego znaczenie i rolę

\footnotetext{
62 J. Ku s a k, Z doświadczeń więziennych samorządów, GP 1967, nr 35, s. II.

63 Tamże.

64 Tamże.
} 
docenia i akcentuje administracja zakładu karnego. Pozytywne efekty wychowawcze mogą być osiągane, jeśli w zakładzie karnym powstaje sprzyjający klimat do działalności zespołów o charakterze samorządowym"65. W skuteczność tak rozumianej metody wychowawczej wpisuje się aktywna rola naczelnika więzienia, który winien systematycznie spotykać się z przedstawicielami rad kolektywu, mobilizować i aktywizować więźniów do samowychowania. Jednocześnie autor podkreśla, że „u podstaw pracy kolektywnej z zespołami samorządowymi więźniów muszą leżeć idee wychowania socjalistycznego. Program działania w tym zakresie powinien być sprecyzowany i doprowadzony do świadomości ogółu więźniów"66.

Jednym ze środków realizowania tej metody jest radiowęzeł. Podkreśla się znaczenie właściwego doboru audycji radiowęzłowych, a sens nadzoru wychowawczego polega nie tylko na „adiustacji i kontroli tekstów, ale również na podsuwaniu myśli, wskazówek oraz sposobów rozumienia"67.

Ważne miejsce w systemie oddziaływań resocjalizacyjnych zajmuje nauka oraz praca więźniów. Reedukacyjne walory nauki więźniów stanowią bardzo częsty temat opracowań prezentowanych na łamach "Gazety Penitencjarnej”. W tym miejscu należy podkreślić, że po wojnie, w poszczególnych okresach, zmieniały się nie tylko podstawowe funkcje kształcenia więźniów, lecz także jego organizacja. Jeszcze w końcu lat 50. wprowadzono naukę na poziomie podstawowym w systemie klasowo-lekcyjnym ${ }^{68}$. Zasadność kształcenia skazanych na poziomie podstawowym i zawodowym nie była nigdy negowana. Inaczej przedstawiała się sytuacja z kształceniem na poziomie średnim, które przechodziło różne fazy. Pierwsza po wojnie szkoła średnia (technikum) dla skazanych powstała w więzieniu dla młodocianych w Jaworznie na początku lat 50 . Placówka ta została zlikwidowana w roku 1955 wraz z likwidacją więzienia. Jednak już w roku 1957 w zakładach karnych ponownie zaczęły powstawać technika. W drugiej połowie lat 60. zaczęto ograniczać możliwości nauki w technikach. W roku 1971 podjęto decyzję o likwidacji nauczania w zakładach karnych na poziomie szkoły średniej i zlikwidowano wszystkie technika. Był to przejaw zaostrzania warunków wykonywania kary pozbawienia wolności. Szkolnictwo średnie zaistniało w zakładach karnych ponownie w roku 1975, w postaci średnich studiów zawodowych, a przez pewien czas w latach 1971-1975 na mocy decyzji administracyjnej zostało zlikwidowane ${ }^{69}$.

Dziwi to, że na łamach „Gazety Penitencjarnej” nie jest właściwie poruszana specyfika kształcenia w warunkach szkoły więziennej, a także słabo eksponowane jest zagadnienie kondycji więźnia-ucznia. Należy pamiętać, że to w zasadniczej mierze niski poziom lub zupełny brak doświadczeń edukacyjnych osadzonych determinował ich funkcjonowanie w roli ucznia. Przeciętny uczeń szkoły przywię-

\footnotetext{
${ }^{65}$ Tamże.

66 Tamże.

67 Z. L e n a r t o w i c z, Wychowawcza rola radiowęzłów, GP 1968, nr 52, s. II.

${ }^{68}$ Wcześniej nauczanie miało charakter kursowy i doraźny. Często odbywało się w celach więziennych.

${ }^{69}$ R. Szczepanik, Kształcenie w warunkach izolacji więziennej, [w:] Andragogika a grupy dyspozycyjne społeczeństwa, red. W. Horyń, J. Maciejewski, Wrocław 2010.
} 
ziennej tamtego okresu był analfabetą lub posiadał wykształcenie podstawowe, ponadto cechował się określonym poziomem demoralizacji i negatywnym stosunkiem do nauki ${ }^{70}$. Natomiast analiza treści artykułów poświęconych problematyce kształcenia przywięziennego każe sądzić, że do ważniejszych trudności, na jakie wskazywali nauczyciele, należało zróżnicowanie wiekowe uczniów (w jednej klasie znajdowali się uczniowie między 16 a 35 rokiem życia) ${ }^{71}$ oraz nieusprawiedliwione absencje ${ }^{72}$.

Akcentowano wychowawcze zadania szkoły przywięziennej ${ }^{73}$. Wiele miejsca poświęcano wychowaniu patriotycznemu, a także podnoszono rozwiązania metodyczne w tym zakresie. Najwłaściwszą lekcją dla wychowania patriotycznego czyniono nauczanie języka polskiego oraz prezentację biografii wybitnych Polaków (np. Skłodowska-Curie, Waryński, Modrzejewska). Zabiegi te „dają dorosłym ludziom, zwłaszcza «urodzonym w niedzielę» sporo do myślenia. [...] Uczniowie dochodzą do wniosku, że pracą na różnych stanowiskach można służyć narodowi, pomnażać jego dobra i rozsławiać dobre imię"74. W tym miejscu warto zwrócić uwagę, że w 1968 r. we wszystkich więzieniach w województwie wrocławskim wprowadzono przedmiot wychowanie obywatelskie i patriotyczne. Program zajęć oparto na programie zasadniczej szkoły zawodowej. W zajęciach uczestniczyli wszyscy więźniowie. Punktem wyjścia były dwie godziny tygodniowo, ale pula ta „W zależności od istniejących potrzeb i zainteresowania może być zwiększona"75. Zajęcia te prowadzone były przez nauczycieli i wychowawców. Wśród form prowadzenia zajęć znajdowały się: pogadanki, prelekcje, rozmowy i dyskusje ilustrowane filmem, audycją telewizyjną, lekturą i artykułami z prasy. Autorzy projektu nie ukrywali, że prócz zasadniczego celu tych zajęć, jakim jest kształtowanie postaw obywatelskich i patriotycznych, ważne miejsce zajmuje możliwość lepszego niż dotychczas poznania postaw więźniów, ich światopoglądu, co tym samym ułatwi dostosowanie określonych metod wychowawczych. Formułowali wniosek, że „inicjatywa wrocławska nie stanowi improwizacji, ale jest dokładnie przemyślaną i zaplanowaną akcją"76.

Najważniejsze miejsce wśród artykułów poświęconych problematyce wychowawczego oddziaływania na skazanego znajdują opracowania prezentujące zagadnienia pracy. Regulamin odbywania kary pozbawienia wolności określał w sposób wyraźny obowiązek pracy każdego więźnia. Organizowanie i przebieg pracy więźniów przysparzały określonych problemów tkwiących nie tylko w negatywnej postawie osadzonych wobec pracy, lecz także w kwestiach organizacyjnych oraz problemach wychowawczych. Na łamach „Gazety Penitencjarnej” problematyka ta jest często podnoszona, formułowane są praktyczne zalecenia

\footnotetext{
70 Tamże.

71 S. Tu b e k, Edukacja i reedukacja, GP 1970, nr 98, s. II.

72 Z. Le na r to w i c z, Nauczyciel to także wychowawca, GP 1968, nr 63, s. I.

73 J. Ko re c k i, B. P a w l a c z y k, Podstawa reedukacji-praca i nauczanie, GP 1970, nr 109, s. II.

74 S. Tubek, Wychowanie w szkole przywięziennej, GP 1969, nr 81, s. III.

75 Wychowanie obywatelskie i patriotyczne, GP 1968, nr 64, s. II.

76 Tamże.
} 
minimalizujące trudności wychowawcze. Do metod wychowawczych proponowanych funkcjonariuszom należało m.in. stałe informowanie więźniów za pomocą zestawień i wykresów o dziennych, miesięcznych i rocznych planach produkcyjnych oraz bieżącym wykonaniu przez poszczególne brygady własnych zadań. Formułowano sądy życzeniowe, wynikające z realizacji podobnego przedsięwzięcia, które zawierają się np. w następującym stwierdzeniu: „W czasie kilkumiesięcznej praktyki stwierdzamy, że system ten wywołał u większości więźniów właściwą społecznie postawę - wyzwolił u nich poczucie odpowiedzialności za powierzony odcinek pracy, poczucie odpowiedzialności za jakość produkowanych wyrobów i ich udział w osiągnięciach całej brygady"77. Podkreślano wychowawcze walory kolektywizacji pracy więźniów oraz wykorzystanie „względów natury ambicjonalnej"78. Autor opracowania ubolewa, że pewna liczba więźniów przejawia wciąż bierną postawę wobec pracy, dlatego też należy sięgnąć tu po bardziej złożone i przemyślane metody oddziaływania penitencjarnego. „Jest nią stałe rozwijanie zakładowego współzawodnictwa pracy"79. Podkreślane są reedukacyjne walory pracy, a wśród nich „wydobywanie więźniów ze stanu psychicznego załamania, apatii i przygnębienia oraz przeświadczenia, że na nic już nie są potrzebni. Tym samym stworzyliśmy im warunki do zadowolenia ze swoich osiągnięć i przydatności dla zakładu pracy i całego społeczeństwa"80.

Kolejne metody oddziaływania wychowawczego to: wnioskowanie w sprawie ulg, pochwał i wynagrodzenia za pracę. W sposób wyraźny podkreśla się, iż tylko ci więźniowie, którzy podejmują pracę, mogą liczyć na wsparcie kierownictwa zakładu karnego i pomoc w rozwiązywaniu skomplikowanych spraw w warunkach życia więziennego. Podnosi się wartość pracy więźniów przede wszystkim w dwóch aspektach. Po pierwsze, zdobyte podczas odbywania kary umiejętności i kwalifikacje stworzą możliwość podjęcia „uczciwej” pracy po opuszczeniu zakładu karnego, kolejno zaś podkreśla się znaczenie wykształcenia i kwalifikacji zawodowych „byłych” więźniów dla możliwości „zwrócenia społeczeństwu zgodnie z jego wymaganiami i potrzebami gospodarki narodowej"81.

$\mathrm{Na}$ podstawie opisu doświadczeń organizacyjnych konkretnych zakładów karnych, zwłaszcza analizy błędów i niedociągnięć, formułowane są zalecenia i przestrogi dla wychowawców, np. wskazuje się na brak właściwego doboru więźniów na kursy i szkolenia. Dla przykładu opisano konsekwencje sytuacji, gdy zobligowano wszystkich więźniów do udziału w kursach krawieckich, bez uprzedniego poznania predyspozycji osadzonych oraz ich planów na przyszłość. Podkreślano również mankamenty kierowania więźniów „na siłę” do pracy tam, gdzie jest miejsce, bez uwzględnienia ich kwalifikacji i możliwości, a także bez szans na kontynuowanie danego rodzaju zajęć po opuszczeniu zakładu karnego. W ten

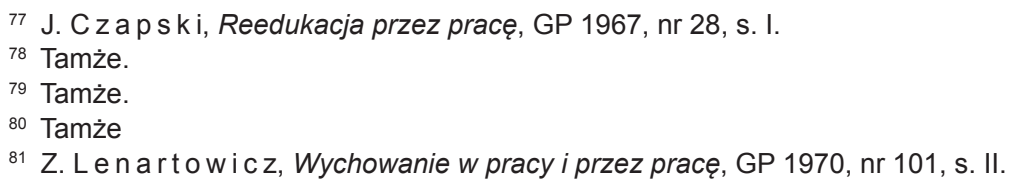


sposób wzmacnia się postawa bierności i jawnej niechęci więźniów do podejmowania szkoleń i wykonywania prac, które zupełnie leżą poza ich możliwościami i zainteresowaniami. Konsekwencje takiej sytuacji opisywane są w sposób następujący: „Popadają w nałóg lenistwa, gdyż to co robią aktualnie, robią pod przymusem. Nie rozwijają w sobie również zmysłu nowatorskiego i inicjatywy, gdyż nie są to kierunki ich zainteresowań" ${ }^{2}$. Szacowano, że podobne problemy są udziałem co najmniej $50 \%$ ogółu więźniów.

Analogiczne kwestie opisuje Zbigniew Lenartowicz w artykule pt. Wychowawca w przedsiębiorstwie. Autor krytykuje sytuację, gdy „pedagogiczną sztukę przekonywania zastępuje się wyłącznie regulaminowym nakazem"83. Postuluje konieczność wnikliwszego poznawania więźnia. Praca jest obowiązkiem każdego więźnia, dla celów resocjalizacyjnych nie jest jednak bez znaczenia to, czy obowiązek ten wykonywany będzie mechanicznie i pod groźbą sankcji, czy też ze świadomością ukształtowania pod wpływem możliwości wyboru miejsca i charakteru pracy. Zwiększeniu aktywności w pracy służyć mają takie metody, jak „współzawodnictwo, Klub Przewodnika Pracy, Klub Racjonalizatora, omawianie metod pracy zespołowej w brygadzie, dyskusje poświęcone sposobom usprawniania organizacji pracy i inne. Kierowanie więźniów do pracy nie może być wyłączną kwestią przedsiębiorstwa, ale powinien uczestniczyć w tym procesie wychowawca i psycholog więzienny"84.

Osłabiona kontrola wychowawcza w przedsiębiorstwie, rozluźnienie dyscypliny, nieprzygotowanie personelu zakładów produkcyjnych do pracy wychowawczej ze skazanymi stanowi poważne przeszkody w procesie wykorzystywania resocjalizacyjnych walorów pracy więźniów ${ }^{85}$. Zbyt często w celu mobilizowania więźniów do pracy sięga się po środki dyscyplinarne, rzadko po perswazję, rozmowy, nie wykorzystuje się (mimo wyraźnych zaleceń) wpływu rodziny i osób bliskich na zmianę postaw więźnia. Działy penitencjarne w niedostatecznym stopniu dążą, by więzień szkolił się na kursach zawodowych. Lekceważą poglądy o zatrudnieniu więźniów jako podstawowej formie resocjalizacji. Dlatego też autorzy artykułów podejmujących problematykę pracy więźniów postulują nadanie jej określonej rangi, a nie traktowanie jej jako obowiązku i sprowadzanie do przymusu ${ }^{86}$.

W aspekcie organizowania więźniom (i byłym więźniom) środowiska pracy podkreśla się, że ustrój socjalistyczny, w odróżnieniu od kapitalistycznego, sprzyja procesowi resocjalizacji. Krytyce poddaje się rozwiązania w państwach kapitalistycznych, w których współpracę zakładów karnych ze społeczeństwem ogranicza się do zagadnień opiekuńczych i postpenitencjarnych, natomiast w sposób marginalny traktowane jest wykorzystanie „czynnika społecznego” wobec kwestii zatrudnienia więźniów i nauczania zawodu. „Diametralnie różny

82 J. Czapski, Reedukacja..., s. I.

83 Z. Le narto wi c z, Wychowawca w przedsiębiorstwie, GP 1969, nr 69, s. II.

84 Z. L e na r to w i c z, Partnerzy pracy wychowawczej, GP 1970, nr 102, s. II.

85 Por. J. Maje r, Uczyć dobrej roboty, GP 1970, nr 101, s. II.

${ }^{86}$ J. Kore cki, B. P a w la czuk, Wychowawczy aspekt zatrudnienia, GP 1970, nr 113, s. III. 
zakres możliwości istnieje w ustroju socjalistycznym, w którym społeczeństwo poprzez swoich przedstawicieli - bierze udział w sprawowaniu władzy"87. Konieczność angażowania społeczeństwa w proces resocjalizacji więźniów zestawia się $z$ celem wykonywania kary pozbawienia wolności, jakim jest „przygotowanie osoby skazanej do życia społecznego za pomocą całego zespołu środków wychowawczych, jak: praca, nauka, zajęcia k.o. oraz objęcie jej opieką postpenitencjarną po odbyciu kary" ${ }^{\prime 8}$. W ramach organizowania i koordynowania współpracy zakładów karnych ze społeczeństwem utworzono - wzorem rozwiązań radzieckich - rady penitencjarne ${ }^{89}$. Początkowo polskie rady penitencjarne pokrywały się $z$ działalnością klubów dyskusyjnych dla funkcjonariuszy SW. Następnie zostały one poszerzone o nowych członków - przedstawicieli organizacji społecznych, zakładów pracy zatrudniających więźniów, instytucji partyjnych i związkowych. „Rady penitencjarne w powiększonym składzie postawiły sobie za cel przede wszystkim udzielanie pomocy zakładom karnym w zakresie pracy wychowawczej z więźniem i świadczeniu opieki postpenitencjarnej [...] sprzyjało temu porozumienie zawarte przez ministra sprawiedliwości z Zarządem Głównym ZMS i ZMW w sprawie opieki nad więźniem młodocianymi [...] wydanie pisma okólnego zalecającego radom zakładowym przełamywanie szkodliwych oporów i uprzedzeń przy zatrudnianiu osób zwolnionych z zakładów karnych [...] zacieśnienie bezpośrednich kontaktów administracji zakładów karnych z kooperującymi przedsiębiorstwami i zakładami pracy, ZMS, OHP, z kuratorami sądowymi [...] z instancjami partyjnymi na swoim terenie" 90 . Członkowie rad penitencjarnych brali udział z rozmowach wychowawców ze szczególnie trudnymi więźniami, uchylającymi się od podjęcia nauki i pracy. Rady penitencjarne miały charakter łącznika pomiędzy zakładem karnym i społeczeństwem.

Tuż po II wojnie światowej dominująca ideologia sytuowała przestępców w roli wrogów narodu. Bezwzględnie odrzucano wszelki dorobek dotychczasowej polskiej penitencjarystyki oraz zerwano $z$ tradycją i filozofią przedwojennego podejścia w traktowaniu więźniów. Kwestie resocjalizacyjno-poprawcze właściwie nie znajdowały swojego miejsca $w$ istniejącym tuż po wojnie systemie stosowania kary pozbawienia wolności, a pewną egzemplifikacją takiego podejścia w traktowaniu przestępców było to, że podstawowym kryterium oceny kandydata na funkcjonariusza była „umiejętność posługiwania się bronią i przekonanie, że we właściwą stronę kieruje lufę"91.

\footnotetext{
87 Z. Le na r to w i c z, Więzienia i społeczeństwo..., s. I.

88 Tamże.

89 W Związku Radzieckim funkcjonowały rady metodyczne przy koloniach pracy poprawczej, składające się z przedstawicieli administracji więziennej, organizacji społecznych i instytucji partyjnych.

90 Z. L e n a r to w i c z, Więzienia i społeczeństwo..., s. I.

91 K. P a w la k, Polska kadra penitencjarna..., s. 8.
} 
Istotnym momentem powojennej historii więziennictwa była ustawa z 11 września 1956 r. o przejściu więziennictwa ze struktur Ministerstwa Spraw Wewnętrznych do struktur Ministerstwa Sprawiedliwości (Dz. U. nr 41, poz. 188). Decyzja o zmianie podległości więziennictwa była bez wątpienia jednym z następstw politycznej „odwilży”, która wiązała się z Polskim Październikiem 195692. Okres następujący bezpośrednio po październiku 1956 był swoistym wyłomem w traktowaniu osób pozbawionych wolności i więziennictwa. Odbywały się liczne wizytacje w więzieniach oraz formułowano wnioski mające na celu zmiany w obrębie traktowania więźniów. Jednakże w następnych latach rzeczywistość więzienna została ponownie ukryta za szczelną zasłoną tajemnicy.

Prezentowane na łamach „Gazety Penitencjarnej” podejście wobec postępowania z przestępcami odbywającymi karę pozbawienia wolności wyraźnie różni się od stanowiska, jakie charakteryzowało więziennictwo w pierwszej dekadzie po II wojnie. Lata 60. przynoszą wyraźny przełom w tworzeniu się systemu penitencjarnego, a polscy penitencjaryści systematycznie, choć powoli, dostosowują polskie rozwiązania do rozwiązań zgodnych z kierunkami światowej polityki penitencjarnej. W oficjalne stanowisko władz więziennictwa, dające podstawy dla koncepcji postępowania z osobami odbywającymi karę pozbawienia wolności, wpisują się idee humanitaryzmu oraz wychowania, którego celem ma być przywrócenie przestępcy społeczeństwu jako pełnowartościowego obywatela.

Mimo tych pozytywnych zmian, w treściach analizowanych artykułów „Gazety Penitencjarnej” nadal dominuje wątek pracy ideologiczno-wychowawczej. W postępowaniu resocjalizującym akcentowana jest konieczność podnoszenia świadomości politycznej więźniów. Miarą kompetencji i kwalifikacji jest dostateczny poziom upartyjnienia funkcjonariuszy służby więziennej. Kształcenie i doskonalenie pracowników kadry penitencjarnej ma przede wszystkim polityczny charakter, a trudności wychowawcze tłumaczone są często niedostateczną ideowością pedagogów. W opracowaniach mających charakter metodyki pracy wychowawczej z więźniami krytykowany jest niedobór określonych treści o charakterze politycznym.

Analiza zawartości i charakteru treści numerów z lat 1967-1970 nie pozostawia wątpliwości, że „Gazeta Penitencjarna” jest lojalna wobec władzy, a kwestię „wychowania przestępców” traktuje jako działania na rzecz wzmacniania istniejącego ustroju socjalistycznego. Wszystkie artykuły, także te o charakterze naukowym, są nasycone ideologią polityczną. Towarzyszy temu uproszczona metodologia publikowanych wyników badań oraz powierzchowność głoszonych sądów. Semantyczno-znaczeniowy charakter słownictwa i frazeologii tekstów - silne naznaczenie treściami ideologicznymi, marksistowskimi, lewicowymi i partyjnymi - nie pozostawia wątpliwości co do politycznego charakteru służby więziennej w okresie PRL.

92 Należy zaznaczyć, że więziennictwo funkcjonowało w strukturach Ministerstwa Sprawiedliwości w okresie międzywojennym. 